Sławomir Kołata

Uniwersytet Papieski Jana Pawła II w Krakowie

Wyższe Seminarium Duchowne w Krakowie

\title{
Praktyczny wymiar rozeznawania powołania w seminarium duchownym w świetle nowego Ratio fundamentalis institutionis sacerdotalis
}

\section{Wprowadzenie}

W obszarze formacji seminaryjnej proces rozeznawania ma swój specyficzny charakter. Kandydat do kapłaństwa, jak każdy chrześcijanin, postępuje w umiejętności rozeznawania duchowego, niemniej jednak sprawdzian jego przylgnięcia do Chrystusa odbywa się w szczególnym kontekście. W istocie idzie przecież o odpowiedź na konkretne pytanie: „Czy Bóg rzeczywiście powołuje mnie do kapłaństwa służebnego?". Jest ono zasadnicze i z pewnością nurtuje człowieka znacznie wcześniej zanim podejmie decyzję o pojawieniu się w progach seminarium. Wielu kandydatów w czasie rozmów rekrutacyjnych wspomina wręcz swoje dziecięce natchnienia powołaniowe. Większość natomiast 
odwołuje się do czasu gimnazjum czy liceum. Raz po raz do furty seminaryjnej pukają również kandydaci w wieku dorosłym, przekraczający 35. rok życia. Powołanie objawia się nie tylko w różnych okresach życia, ale także $w$ rozmaitych okolicznościach, przy bardzo różnorodnej osobistej dyspozycji psychofizycznej. Jest zatem rzeczą zrozumiałą, że Kościół ma za zadanie otoczyć troską rodzące się powołanie do kapłaństwa i pomóc w jego rozeznawaniu przez cierpliwe towarzyszenie ${ }^{1}$.

Pomoc Kościoła w rozeznawaniu powołania nie jest jedynie biernym asystowaniem. Warto podkreślić, że głos Kościoła jest w tym względzie decydujący. Rozeznawanie rozgrywa się jakby na dwóch płaszczyznach: osobistej, w której człowiek rozpoznaje wewnętrzny głos Boży, oraz społeczno-eklezjalnej, w której Kościół weryfikuje i ostatecznie dopuszcza do święceń kapłańskich. Powołanie jest darem, bo pochodzi z Bożego wyboru: „Nikt sam sobie nie bierze tej godności, lecz tylko ten, kto jest powołany przez Boga, jak Aaron” (Hbr 5,4). Domaga się ono wielkodusznego przyjęcia przez samego powołanego, ale również oficjalnego uznania przez Kościół. „Kościelne rozeznanie włącza indywidualne powołanie do posługi kapłańskiej jako takiej. Kandydat do kapłaństwa winien przyjąć powołanie, nie stawiając żadnych osobistych warunków, lecz akceptując normy i wymagania, które stawia Kościół, świadomy własnej odpowiedzialności”2.

Głównym źródłem stanowiącym światło dla obecnego przedłożenia jest najnowszy dokument Kongregacji ds. Duchowieństwa zatytułowany: Dar powołania do kapłaństwa. Ratio fundamentalis institutionis sacerdotalis opublikowany w Watykanie 8 grudnia 2016 r. W pierwszej części artykułu przyjrzano się ogólnej naturze procesu rozeznawania poprzez rozpatrzenie poszczególnych jego etapów. Rozwinięcia i pogłębienia refleksji nad tym zagadnieniem dokonano przez analizę obszarów dramaturgii powołaniowego rozeznawania. W ostatniej części podjęto się szerszego spojrzenia na proces rozeznawania z perspektywy zaangażowania środowiska formacyjnego. Przytoczone kwestie prak-

${ }^{1}$ Por. Jan Paweł II, Pastores dabo vobis, AAS 84(1992), s. 657-804 [dalej: PDV], 34.

${ }^{2}$ PDV 35. 
tyczne będą prezentowane w optyce kilkuletniego doświadczenia autora jako formatora w Wyższym Seminarium Duchownym Archidiecezji Krakowskiej.

\section{Etapy rozeznawania w seminarium}

Rozeznawanie powołania nie jest bynajmniej czynnością jednorazową, w istocie to zadanie na całe życie. Warto przeanalizować poszczególne etapy tego procesu, uwzględniając przede wszystkim okres formacji seminaryjnej.

\section{Rekrutacja}

Pierwsza weryfikacja kandydata do kapłaństwa z perspektywy instytucjonalnej dokonuje się już na poziomie rekrutacji. W tym początkowym stadium rozeznawania należy wykluczyć formalne przeszkody i nieprawidłowości do przyjęcia święceń wynikające z przepisów Kodeksu prawa kanonicznego ${ }^{3}$.

Najpierw weryfikowana jest kondycja zdrowotna. Wymogi odnoszące się do zdrowia fizycznego wykluczają choroby uniemożliwiające posługę kapłańską, np. głuchota, ślepota, nieprzekraczalne wady wymowy czy choroby wymagające terapii i stałej opieki. Szczególnie zwraca się uwagę na padaczkę, celiakię i alkoholizm. Dwie ostatnie choroby odnoszą się do problemów związanych ze spożywaniem postaci eucharystycznych. Określa się również stan zdrowia psychicznego - na podstawie testu i wywiadu, który przeprowadza kompetentny psycholog współpracujący z seminaryjnymi formatorami. Nieprawidłowością do przyjęcia święceń jest amencja lub inna poważna choroba psychiczna ${ }^{4}$. Diagnoza zdrowia psychicznego pomaga również w rozeznawaniu uza-

${ }^{3} \mathrm{~W}$ praktyce seminarium krakowskiego dokonuje się to przez analizę szeregu warunków brzegowych, zawartych $\mathrm{w}$ ankiecie spisywanej w trakcie rozmowy z kandydatem.

${ }^{4}$ Por. Kodeks prawa kanonicznego [dalej: KPK 1983], kanon 1041 § 1. 
leżnień, zespołu DDA czy innych psychicznych deficytów, które przyszły alumn będzie musiał przepracować w trakcie formacji.

Niezwykle ważnym wymogiem stawianym kandydatowi jest publiczna postawa wiary. Wśród nieprawidłowości w tym obszarze trzeba zwrócić uwagę szczególnie na przestępstwa apostazji, herezji i schi$z m y^{5}$ oraz na symulowanie sprawowania sakramentów ${ }^{6}$. Takie sytuacje praktycznie się nie zdarzają, o wiele bardziej możliwe są dziś przypadki nagłego nawrócenia, na skutek którego neofita chce zostać kapłanem. Trzeba wówczas roztropnie rozeznać w porozumieniu $\mathrm{z}$ właściwym ordynariuszem czas dostatecznego utwierdzenia w wierze ${ }^{7}$. Bardzo ważna jest weryfikacja w dziedzinie przestępstw przeciwko życiu. Wykluczające jest przede wszystkim zabójstwo, a w szczególności współudział $\mathrm{w}$ aborcji ${ }^{8}$, ale także nieumyślne spowodowanie śmierci czy próba samobójcza9.

Konieczna do weryfikacji i rozeznania jest również dziedzina związana z płciowością, która wprost wpływa na możliwość podjęcia w przyszłości zobowiązania celibatu. Przeszkodą jest tu przede wszystkim zawarcie związku małżeńskiego ${ }^{10}$, ale także moralnie nieuporządkowane czyny, takie jak: pedofilia, kazirodztwo, prostytucja czy gwałt. Osobnym, bardzo nabrzmiałym w ostatnim czasie, problemem jest orientacja homoseksualna. „Kościół głęboko szanując osoby, których dotyczy ten problem, nie może dopuszczać do seminarium ani do święceń tych, którzy praktykują homoseksualizm, wykazują głęboko zakorzenione tendencje homoseksualne lub wspierają tak zwaną kulturę gejowską" ${ }^{11}$. Ważne jest również roztropne rozeznanie czasu, który upłynął od ewentualnej ostatniej relacji seksualnej z kobietą. W prak-

\footnotetext{
${ }^{5}$ Por. KPK 1983, kanon 1041 § 2.

${ }^{6}$ Por. KPK 1983, kanon $1041 \S 6$.

${ }^{7}$ Por. KPK 1983, kanon $1042 \S 3$.

${ }^{8}$ Por. KPK 1983, kanon $1041 \S 4$.

${ }^{9}$ Por. KPK 1983, kanon $1041 \S 5$.

${ }^{10}$ Por. KPK 1983, kanon $1041 \S 3$.

${ }^{11}$ Kongregacja ds. Wychowania Katolickiego, Instrukcja dotyczaca kryteriów rozeznawania powołania w stosunku do osób $z$ tendencjami homoseksualnymi w kontekście
} 
tyce przyjmuje się minimum dwa lata życia w czystości przed wstąpieniem do seminarium.

W trakcie procedury rekrutacyjnej konieczny jest również wgląd w sferę prawa własności. Przeszkodą są w tej dziedzinie wielokrotne akty kradzieży, malwersacje i nadużycia finansowe, a uregulowania wymagają zaciągnięte długi czy kredyty. Z grona ubiegających się o wstąpienie do seminarium wykluczają się również ci, którzy popełnili przestępstwo wobec prawdy, np. krzywoprzysięstwo, poświadczenie nieprawdy w sądzie, fałszowanie dokumentów itp.

Kandydat, który pozytywnie przeszedł proces rekrutacji, staje się seminarzystą i podejmuje formację do kapłaństwa. Można ją podzielić na cztery duże etapy, w czasie których rozeznawanie ma swoją odrębną specyfikę.

\section{Rok propedeutyczny}

Ratio fundamentalis wspomina i wyraźnie zaleca najpierw etap propedeutyczny, który w praktyce stosowany jest w niewielu seminariach w Polsce ${ }^{12}$. Z punktu widzenia przygotowania do kapłaństwa jest to jednak czas, w którym ma się dokonać prawdziwe i właściwe powołaniowe rozeznanie w ramach życia wspólnotowego ${ }^{13}$. Celem tego wstępnego okresu jest stworzenie trwałego fundamentu pod życie duchowe i pomoc w uświadomieniu alumnom własnych zasobów i deficytów osobowościowych. Realizacja tych zamierzeń ma się dokonywać we wspólnocie odrębnej od seminarium, z własnymi formatorami

przyjmowania ich do seminariów i przyjmowania do święceń, „L'Osservatore Romano” 5(2006), 2.

${ }^{12}$ W roku formacyjnym 2017/2018 tylko dwa seminaria (w Koszalinie i Katowicach) wykazują ilość alumnów roku propedeutycznego w pełnym zakresie, czyli jako rok zerowy. Niektóre seminaria, na przykład w Warszawie czy we Wrocławiu, mimo że posiadają domy propedeutyczne oddzielne od zasadniczego budynku seminarium, to jednak traktują alumnów roku wstępnego jako alumnów I roku.

${ }^{13}$ Por. Kongregacja ds. Duchowieństwa, Dar powołania do kapłaństwa. Ratio fundamentalis institutionis sacerdotalis, „L'Osservatore Romano”, Supplement, 8 XII 2016 [dalej: RFIS], 60. 
i w osobnym budynku. Papież Franciszek, przemawiając do Kongregacji ds. Duchowieństwa, zwraca uwagę, że na tym etapie trzeba dobrze przeanalizować drogę powołania, zadając konkretne pytania: „Czy jest to od Pana Boga, czy ten człowiek jest zdrowy, czy ten człowiek jest zrównoważony, czy ten człowiek jest zdolny dawać życie, ewangelizować, czy ten człowiek jest zdolny, by założyć rodzinę, i wyrzec się jej, by pójść za Jezusem"14. Ma to być zatem poważna selekcja kandydatów do następnego etapu, który jest czasem studiów filozoficznych.

\section{Czas bycia uczniem}

W koncepcji Ratio fundamentalis studium filozofii nazwane zostało okresem „bycia uczniem”. Chodzi więc o zintegrowany profil formacji oparty na naśladowaniu Chrystusa. Rozeznawanie drogi życia musi dokonywać się przede wszystkim w oparciu o głęboką relację z Mistrzem. Konieczne jest wykorzystanie wszelkich sił, aby naśladując Nauczyciela, pochylić się w pierwszej kolejności nad kształtowaniem własnego charakteru. Relacja z Chrystusem-Pedagogiem ma prowadzić do osiągnięcia solidnej dojrzałości fizycznej, emocjonalnej i społecznej ${ }^{15}$. Dokonuje się to oczywiście przy zaangażowaniu formatorów, którzy mają stałe zadanie wspierania alumna w jego własnej dynamice wzrostu. Nieoceniona jest w tym względzie również pomoc wspólnoty kleryckiej ${ }^{16}$, która wezwana jest do praktyki correctio fraterna (z łac. upomnienie braterskie). Będzie o tym mowa w ostatniej części tego artykułu.

Jest rzeczą niezwykle ciekawą, że najnowsze Ratio na tym etapie formacji zakłada możliwość dopuszczenia seminarzysty do grona kandydatów do święceń. Chodzi o liturgiczny obrzęd wprowadzony przez Pawła VI ${ }^{17}$, w którym Kościół formalnie wybiera i powołuje alumna, aby przygotowywał się do przyjęcia święceń. W praktyce Kościoła

${ }^{14}$ Franciszek, Przemówienie do Zgromadzenia Plenarnego Kongregacji ds. Duchowieństwa, „L'Osservatore Romano” 11(2014), 8.

${ }^{15}$ Por. RFIS 63.

${ }^{16}$ Por. RFIS 65-67.

${ }^{17}$ Por. Paweł VI, List apostolski Ad pascendum, AAS 64(1972), I a. 
w Polsce obrzęd ten sprawowany jest na ogół na około pół roku przed święceniami diakonatu. Wydaje się, że rozeznanie autentyczności powołania jest wówczas bardziej czytelne. Okres „bycia uczniem” ma być uwieńczony osiągnięciem odpowiedniej wolności i wewnętrznej dojrzałości do dalszego etapu formacji, którym jest czas „upodobnienia się do Chrystusa”.

\section{Etap upodobnienia się}

Kolejny etap formacji, określany dotychczas mianem studium teologii, „koncentruje się na upodobnieniu seminarzysty do Chrystusa, Pasterza i Sługi, aby z Nim zjednoczony mógł uczynić z własnego życia dar z siebie dla innych"18. Na płaszczyźnie zewnętrznej kleryk ma okazję zmierzyć się z trudnym świadectwem noszenia stroju duchownego. Kiedy rano zakłada sutannę, odmawia modlitwę: „Przyoblecz mnie, Panie, w nowego człowieka, który według Boga stworzony jest w świętości i sprawiedliwości życia”. Za tym znakiem zewnętrznym idzie szczególna praca nad harmonizowaniem dojrzewania ludzkiego z formacją duchową przyszłego prezbitera. Seminarzyści mają coraz większą możliwość poznawania życia kapłańskiego, a przez to zachęceni są do stopniowego zakorzeniania się w „fizjonomii Dobrego Pasterza"19. Nie do przecenienia na tym etapie jest przystąpienie do posług lektoratu i akolitatu, które dają seminarzyście motywację do głębszego przeżywania misterium Eucharystii w wymiarze Słowa i Ołtarza.

Również na tym etapie rozeznawania może się okazać, że seminarzysta w istocie nie ma powołania do kapłaństwa służebnego. Odpowiednie towarzyszenie alumnowi i jego nowe doświadczenia posług mogą doprowadzić do wniosku, że powołanie odkryte w pierwszym etapie jako prawdopodobne nie jest prawdziwą rzeczywistością. W takiej sytuacji dokument Ratio fundamentalis sugeruje przerwanie for-

\footnotetext{
${ }^{18}$ Por. RFIS 68.

${ }^{19}$ RFIS 69.
} 
macji do święceń ${ }^{20}$. W praktyce zdarza się to zarówno z własnej inicjatywy alumna, jak również na skutek interwencji formatorów.

Etap „upodabniania się do Chrystusa” kończy się ostateczną decyzją o dopuszczeniu do święceń. Biskup właściwego Kościoła partykularnego po wysłuchaniu opinii formatorów, po zbadaniu opinii wiernych, jak również po wyrażeniu pisemnej prośby samego kandydata, może uznać go za zdatnego do święceń w stopniu diakonatu ${ }^{21}$. Z punktu widzenia alumna rozeznającego swoje powołanie powinna to być jednak decyzja ostateczna, również na święcenia kapłańskie. Diakonat jest w tym sensie jedynie stanem przejściowym, ukierunkowanym zdecydowanie na święcenia w stopniu prezbiteratu.

\section{Czas pastoralny i formacja permanentna}

Przed przyjęciem święceń prezbiteratu przewidziany jest jeszcze etap pastoralny, który nazywa się w nomenklaturze Ratio fundamentalis czasem „syntezy powołaniowej"22. Alumni, którzy są już po święceniach diakonatu, podejmują praktyki we wspólnocie parafialnej określonej przez ordynariusza w porozumieniu $\mathrm{z}$ rektorem seminarium. Powołaniu diakona towarzyszą na tym etapie nie tylko formatorzy seminaryjni, ale również duszpasterze parafii, w której odbywa praktykę, na czele z proboszczem. Przyszły kapłan ma okazję do ostatecznej konfrontacji teorii z praktyką. Czas ostatniego roku formacyjnego rozciąga się między pobytem w seminarium, gdzie diakon kończy studia teologiczne i zdaje egzaminy jurysdykcyjne, a pobytem we wspólnocie parafialnej, gdzie spełnia posługę katechetyczną i sakramentalno-duszpasterską właściwą dla jego stanu. Etap ten ma pomóc w zadeklarowaniu przez diakona woli bycia kapłanem w sposób wolny, świadomy i ostateczny ${ }^{23}$. Święcenia kapłańskie kończą czas formacji zasadniczej,

${ }^{20}$ Por. RFIS 72.

${ }^{21}$ Por. RFIS 73.

${ }^{22}$ Por. RFIS 74-79. Warto dodać, że w wielu seminariach w Polsce, w tym także w Wyższym Seminarium Duchownym Archidiecezji Krakowskiej, jest to rok szósty.

${ }^{23}$ Por. RFIS 74. 
która jednak przechodzi w okres formacji permanentnej. Doświadczenie „bycia uczniem Chrystusa” ma przecież towarzyszyć kapłanowi do końca życia. Kapłan każdego dnia powinien rozeznawać i wybierać taki styl posługi, który będzie sprzyjał wierności, ciągłemu nawracaniu się i ożywianiu charyzmatów pasterza. Warto podkreślić, że głównym odpowiedzialnym za formację permanentną jest sam prezbiter ${ }^{24}$. Korzysta on jednak wciąż z możliwości towarzyszenia duchowego w ramach studium stałej formacji kapłańskiej.

\section{Obszary rozeznawania powołaniowego}

Po przeanalizowaniu etapów rozeznawania powołania, które ukazują czasowość tego procesu, warto rozpatrzyć jego wielowymiarowość. Od czasu ukazania się adhortacji Jana Pawła II Pastores dabo vobis wylicza się cztery obszary formacji, a mianowicie: ludzki, duchowy, intelektualny i duszpasterski ${ }^{25}$. We wspólnocie seminaryjnej przyszły kapłan, poddając się integralnemu wzrostowi, ma dążyć do właściwej równowagi pomiędzy wszystkimi powyższymi obszarami.

\section{Rozeznawanie na poziomie osobowości}

Seminarzysta wezwany jest w pierwszej kolejności do postępu duchowego w relacji z Chrystusem - Dobrym Pasterzem. To jednak może się dokonać jedynie wówczas, gdy właściwie uformowane jest człowieczeństwo kandydata do kapłaństwa. Mądrość Ojców Kościoła wyrażona w stwierdzeniu: „Łaska zakłada naturę"26 potwierdzona jest w praktyce popularną radą doświadczonych kapłanów, a wyrażoną w potocznym stwierdzeniu: „Bądź najpierw człowiekiem, a potem księdzem”. Ten, kto chce służyć Kościołowi jako duszpasterz, powinien mieć wystarczającą dojrzałość psychofizyczną, społeczną i moralną ${ }^{27}$.

\footnotetext{
${ }^{24}$ Por. RFIS 82.

${ }^{25}$ Por. PDV 43-59.

${ }^{26}$ Tomasz z Akwinu, Summa I, q. 1, a. 8 ad. 2.

${ }^{27}$ Ror. RFIS 94.
} 
Pod względem fizycznym kleryk ma okazję właściwie rozeznawać potrzebę aktywności motorycznej i odpoczynku, a także zdrowego odżywiania. W warunkach seminaryjnych pomocą w tym mają być dobrze opracowane "zasady życia seminaryjnego". Jest w nich miejsce zarówno na pracę intelektualną, jak i na wysiłek sportowy, ale również na odpowiednią ilość wypoczynku. Najczęściej jednak dopiero okres wakacyjny pokazuje, na ile udaje się seminarzyście wypracować właściwy sposób dysponowania czasem.

Uświadamianie sobie potrzeb fizycznych jest bezpośrednio związane z umiejętnością wglądu w siebie pod względem osobowościowym. Chodzi o rozpoznanie swoich potrzeb psychicznych, które nie korespondują ze świadomą decyzją o kapłaństwie. Są to pewne przestrzenie niespójności, które prowadzą do wewnętrznych konfliktów i przeszkadzają w realizacji powołania w sposób dojrzały ${ }^{28}$. Ważne jest przy tym rozpoznanie temperamentu, aby znając zagrażające tendencje do pielęgnowania wad, jednocześnie widzieć swoje pozytywne cechy wrodzone i na nich budować ${ }^{29}$. Pod czujnym okiem kierownika duchowego seminarzysta jest $\mathrm{w}$ stanie cierpliwie przyglądać się własnemu procesowi dojrzewania emocjonalnego. Ratio fundamentalis przypomina o współpracy kleryka $\mathrm{z}$ formatorami w kwestii otwierania się na historię własnych przeżyć z dzieciństwa i wieku młodzieńczego. Bardzo często jest to zadanie niezmiernie trudne, ale jednocześnie kluczowe dla uświadomienia alumnowi jego zasobów i deficytów w relacjach międzyosobowych. Niebagatelne znaczenie ma zdolność do tworzenia dojrzałych więzi z kobietami ${ }^{30}$. Za radą Jana Pawła II seminarium ma za zadanie pochylać się nad tematem „geniuszu kobiet”, które obecne są w życiu parafialnym i społecznym ${ }^{31}$ i z którymi przyszły duszpasterz będzie współpracował. Okazją do rozeznawania relacji zarówno z kobietami,

${ }^{28}$ Por. W. Rzeszowski, Formacja ludzka w przygotowaniu do kapłaństwa, „Rocznik Teologii Katolickiej”, XV/1 (2016), s. 42.

${ }^{29}$ Por. W. Cyran, Powołanie. Pojęcie, rozeznanie i kierownictwo duchowe, Częstochowa 2003, s. 52-53.

${ }^{30}$ Por. RFIS 94-95.

${ }^{31}$ Por. Jan Paweł II, List do kobiet, AAS 87(1995), 10. 
ale też z mężczyznami każdego wieku i pozycji społecznej są praktyki wakacyjne. Klerycy podejmują te formy aktywności duszpasterskiej na różnych etapach formacji. Pojawiające się w tym czasie doświadczenia uczuciowe i gotowość do ich przepracowania niewątpliwie służą lepszej integracji, zwłaszcza w dziedzinie seksualności. Słusznie zauważa dokument, że alumni przez „iter” formacyjny nie mogą zostać wykluczeni z przestrzeni publicznej, która jest miejscem tworzenia nowych więzi i nowych form wspólnoty ${ }^{32}$. Tą przestrzenią jest również świat cyfrowy, który dziś stanowi poważne wyzwanie do pracy nad osobowością seminarzysty. Możliwość elektronicznej komunikacji z jednej strony jest okazją do zbliżenia $\mathrm{z}$ drugim człowiekiem i daje sposobność do ewangelizacji, ale z drugiej strony może być czynnikiem tworzenia toksycznych relacji i uzależniających zachowań. $Z$ tych względów otwarcie na świat cyfrowy w codziennym życiu wspólnoty seminaryjnej powinno zachodzić w sposób „uważny, spokojny i pozytywny”33.

Formacja ludzka to przestrzeń dojrzewania do właściwie pojmowanej wolności. Podejmowanie słusznych decyzji, należyta ocena sytuacji moralnych czy też zdolność do obiektywnej percepcji osób i zdarzeń są możliwe dzięki dobrze ukształtowanemu sumieniu ${ }^{34}$. W warunkach seminaryjnych okazją do przyglądnięcia się swoim wyborom jest rachunek sumienia, zarówno podczas modlitwy w ciągu dnia, jak również przy wieczornej refleksji w powiązaniu z porannym rozmyślaniem. Wymiar ludzki spotyka się tu z żywym odniesieniem do Chrystusa, który jest centrum formacji duchowej.

\section{Rozeznawanie w formacji duchowej}

Z punktu widzenia procesu rozeznawania $\mathrm{w}$ formacji duchowej chodzi o nabycie umiejętności spojrzenia na Boga i bliźniego „oczami Jezusa”. Zadanie to jest możliwe do realizacji przy właściwym otwar-

\footnotetext{
${ }^{32}$ Por. RFIS 97.

${ }^{33}$ RFIS 98-100.

${ }^{34}$ Por. RFIS 94.
} 
ciu na wewnętrzne poruszenia Ducha Świętego. Postrzeganie w wierze swojego powołania rodzi się z intymnej więzi z Chrystusem, której seminarzysta powinien stale poszukiwać i doświadczać. Pastores dabo vobis wylicza potrójną drogę ugruntowania zażyłości z Mistrzem. Chodzi mianowicie o: rozważanie Słowa Bożego, aktywne uczestnictwo w świętych tajemnicach Kościoła oraz posługę miłości wobec „najmniejszych"35.

$\mathrm{W}$ procesie dojrzewania duchowego nieodzownym elementem jest najpierw Słowo Boże. Znane jest stwierdzenie św. Hieronima, że „nieznajomość Pisma Świętego to nieznajomość Chrystusa" ${ }^{36}$. Proponowaną w formacji metodą studiowania Biblii jest lectio divina. Taki sposób duchowego czytania pozwala na osobiste odniesienie Słowa Bożego do aktualnej sytuacji życiowej. Realizacja rzeczonego postulatu dokonuje się w porannym rozmyślaniu, w świetle którego alumn powinien powoli odkrywać, rozumieć i pokochać swoje własne powołanie. Odpowiedź na Słowo Boże jest zawsze aktem wiary, która staje się właściwym „kryterium osądu i oceny ludzi i rzeczy, wydarzeń i problemów”37.

Kolejnym elementem formacji duchowej jest praktykowanie życia sakramentalnego. W centrum powinna się znajdować Eucharystia, która kształtuje stałą więź z Panem w perspektywie przyszłej posługi przy ołtarzu jako alter Christus. Codzienna Msza Święta ma swoje przedłużenie w adoracji eucharystycznej, przeżywanej w sposób indywidualny przez alumna lub uroczyście we wspólnocie ${ }^{38}$. Wyjątkowa wymiana spojrzeń, która się w tym czasie dokonuje, to niewątpliwie szczególny czas łaski (gr. kairos), w którym Bóg nawiedza przyszłego kapłana. To czas modlitwy, który wraz z Liturgia godzin tworzy kolejną nić zażyłej więzi z Chrystusem ${ }^{39}$. W ramach życia sakramentalnego alumn zobowiązany jest do częstej spowiedzi świętej, która w praktyce semi-

\footnotetext{
${ }^{35}$ PDV 46.

${ }^{36}$ Hieronim, Commentarii In Isaiam, Prologus: CCL 73, 1, za: RFIS 103.

${ }^{37}$ PDV 47.

${ }^{38}$ Zasady życia wspólnego w seminarium krakowskim przewidują wspólnotową adorację w każdy wtorek i czwartek.

${ }^{39}$ Por. RFIS 104-105.
} 
naryjnej ma miejsce w cyklu cotygodniowym. Przedłużona refleksja modlitewna odbywa się ponadto $\mathrm{w}$ ramach trzydniowych rekolekcji ${ }^{40}$. Towarzysząca tym dniom atmosfera ciszy i skupienia sprzyja głębszemu rozeznaniu duchowemu i stopniowemu oddawaniu „własnego życia dla realizacji miłości pasterskiej”"41.

Przygotowanie do posługi miłości, rozumianej jako dawanie siebie braciom, urzeczywistnia się w warunkach seminaryjnych przez wychowanie do posłuszeństwa, celibatu i ubóstwa ${ }^{42}$. Mimo że przyszły kapłan diecezjalny nie ślubuje rad ewangelicznych, to jednak jest zaproszony do przyjęcia stylu życia inspirowanego logiką Ewangelii. W pierwszej kolejności „być posłusznym” oznacza słuchać z całą pokorą Słowa Bożego. Ważne jest, aby zarówno seminarzysta, jak i towarzyszący mu formatorzy otwierali się na wolę Boga w procesie stopniowego odkrywania powołania ${ }^{43}$. Ubóstwo również bierze swój początek z posłuszeństwa, jakie Jezus okazuje Ojcu Niebieskiemu. Posłuszeństwo to prowadzi Syna Bożego do całkowitego ogołocenia, aż po krzyż. Do takiego ubóstwa jest zaproszony przyszły kapłan, który musi uświadamiać sobie, jak wiele napięć w życiu wspólnotowym i parafialnym rodzi się z niewłaściwego stosunku do dóbr materialnych ${ }^{44}$. Znakiem całkowitego oddania się Bogu i bliźniemu jest czystość w celibacie. $R a-$ tio fundamentalis przestrzega: „Byłoby wielce nierozważne dopuścić do sakramentu świeceń seminarzystę, który nie osiągnął, pogodnej i wolnej dojrzałości uczuciowej, wiernej w czystości celibatu”" ${ }^{45}$. Idzie o to, aby kleryk zrozumiał ewangeliczną moc tego daru, doceniając jednocześnie wartość stanu małżeńskiego. Praktycznemu rozeznaniu

${ }^{40} \mathrm{~W}$ seminarium krakowskim trzydniowe rekolekcje odbywają się dwa razy w roku: na początku roku formacji oraz w Wielkim Poście.

${ }^{41}$ RFIS 108.

${ }^{42}$ Por. PDV 49.

${ }^{43}$ Por. A. Begasse de Dhaem, Jezus, Formator formatorów. Wspólnota uczniów jako przestrzeń wzrastania $w$ wierze, [w:] W. Wójtowicz (red.), Formacja seminaryjna jako przestrzeń wzrastania $w$ wierze, Niepokalanów 2017, s. 31.

${ }^{44}$ Por. A. Begasse de Dhaem, Jezus, Formator formatorów, s. 32.

${ }^{45}$ RFIS 110. 
w tym względzie sprzyjają częste spotkania z małżonkami i rodzinami, słuchanie ich świadectw, zarówno w trakcie spotkań duszpasterskich w murach seminaryjnych, jak i w warunkach różnych doświadczeń rekolekcyjnych czy pielgrzymkowych.

\section{Rozeznawanie intelektualno-duszpasterskie}

W kontekście problemu rozeznawania warto wspólnie przemyśleć kolejne dwa wymiary formacji. Formacja intelektualna ma mieć przede wszystkim motywację duszpasterską. Studia filozoficzno-teologiczne są niezwykle ważne z racji zdobywania przez przyszłego kapłana niezbędnych kompetencji w dziedzinie wiedzy, kultury i umiejętności przekazu prawd objawionych. Warto zauważyć, że daleko posunięty pluralizm w wielu dziedzinach życia społecznego, w tym także we wspólnocie Kościoła, wymaga umiejętności krytycznego rozeznawania. To dostrzeganie znaków czasu będzie tym bardziej skuteczne, jeśli alumn zdoła zintegrować zdobywanie wiedzy z poszczególnych dyscyplin naukowych z osobistym doświadczeniem Boga ${ }^{46}$. Wydaje się, że na styku teorii i praktyki duszpasterskiej znajduje się szczególnie studium teologii pastoralnej. Ma ono uzdolnić przyszłych kapłanów do rozumienia współczesnego człowieka i do głoszenia ewangelicznego orędzia w sposób odpowiadający współczesnej kulturze ${ }^{47}$.

Wymiar duszpasterski formacji seminaryjnej stawia sobie za cel doprowadzenie alumna do wolności w sferze apostolatu tak, by stawał się on przewodnikiem wspólnoty na wzór Dobrego Pasterza. Przyszły kapłan ma być przede wszystkim „ekspertem w sztuce rozeznawania duszpasterskiego, tj. zdolnym do uważnej analizy konkretnych sytuacji i do trafnej oceny w wyborach i decyzjach" ${ }^{\text {"4 }}$. Cel ten może być osiągnięty głównie na drodze mądrego wsłuchiwania się w głos tych, którzy tworzą środowisko duszpasterskiego oddziaływania. Seminarzysta po-

\footnotetext{
${ }^{46}$ Por. PDV 51.

${ }^{47}$ Por. PDV 57.

${ }^{48}$ RFIS 120.
} 
winien uczyć się nade wszystko ewangelicznego stylu słuchania, który uwalnia duszpasterza „od pokusy abstrakcyjności, protagonizmu, przesadnej pewności siebie i oziębłości, co uczyniłoby z niego «księgowego», zamiast «dobrego samarytanina»" 49 .

Proces dochodzenia do takiego pasterskiego stylu bycia powinien być autentycznie zainicjowany $\mathrm{w}$ ramach pastoralnej formacji seminaryjnej. W czasie roku akademickiego służą temu celowi spotkania z różnymi duszpasterstwami, wśród których można wymienić: duszpasterstwo powołań, chorych, więzienne, młodzieży (Ruch Światło-Życie czy Grupy Apostolskie), rodzin itp.

Naturalne przedłużenie tego procesu powinno jednak konkretyzować się w parafii, czyli w żywej wspólnocie wierzących ${ }^{50}$. W czasie praktyki duszpasterskiej ${ }^{51}$, o której wspominano już przy omawianiu pastoralnego etapu formacji, przyszły kapłan może wypracowywać $\mathrm{w}$ sobie postawę pasterską. Urzeczywistnia się to przez czerpanie wzoru ze stylu bycia proboszcza czy innych spotykanych księży. Zdobywane w ten sposób doświadczenia mają mieć charakter służebny i mogą realizować się przez wierne wypełnianie posług lektora, akolity, a później diakona. Zadania służebne w praktyce parafialnej alumn realizuje nie tylko w zgromadzeniu liturgicznym, ale również spotykając się $\mathrm{z}$ różnymi grupami parafialnymi. Cennym źródłem doświadczeń są relacje nawiązane zarówno z dziećmi, młodzieżą, ale także z rodzinami, a w szczególności z osobami chorymi ${ }^{52}$ czy w podeszłym wieku.

${ }^{49}$ RFIS 120.

${ }^{50}$ Por. PDV 58.

${ }^{51}$ Warto zaznaczyć, że w trakcie formacji seminaryjnej w seminarium krakowskim alumni zobowiązani są nie tylko do praktyki na ostatnim roku formacji, ale również odbywają praktyki katechetyczne w trakcie roku akademickiego i miesięczną praktykę pastoralno-katechetyczną $\mathrm{w}$ wyznaczonej przez seminarium parafii we wrześniu bezpośrednio poprzedzającym piąty rok formacji.

${ }^{52}$ Klerycy seminarium krakowskiego mają także możliwość kontaktu duszpasterskiego z chorymi zarówno po pierwszym roku formacji (Szpital Dziecięcy w Prokocimiu), jak i po drugim roku formacji (turnusy rehabilitacyjne z niepełnosprawnymi). 
W atmosferze wspólnoty parafialnej przyszły kapłan spotyka się zatem z rzeczywistością Kościoła lokalnego jako „wspólnoty wspólnot”. Uczy się współpracy z różnymi członkami Kościoła, zarówno duchownymi jak i świeckimi. W tej współpracy konieczne jest rozeznawanie i właściwe uznawanie różnych charyzmatów, odmiennych odpowiedzialności, które mają jednak tworzyć jedną wspólną rzeczywistość Mistycznego Ciała Chrystusa. Zwłaszcza w kontakcie ze świeckimi alumn powinien posiąść umiejętność współdziałania i prowadzenia do odkrycia misyjnego zadania „przekształcania świata ewangelicznym światłem"53.

\section{Funkcje środowiska formacyjnego w procesie rozeznawania powołania}

Dotychczasowe rozważania nad czasowością i wielowymiarowością rozeznawania powołania prowadzone były z perspektywy seminarzysty. Nie ulega wątpliwości, że sam kandydat do święceń jest głównym podmiotem rozeznawania własnego powołania. Istotą formacji seminaryjnej jest ostatecznie samowychowani ${ }^{54}$. Odwracając perspektywę, warto prześledzić drogę powołania od strony środowiska, z którym styka się przyszły ksiądz. Biorąc pod uwagę to, że kleryk w ciągu roku przebywa co najmniej cztery miesiące poza domem formacyjnym, trzeba przyjrzeć się nie tylko społeczności seminaryjnej, ale również pozaseminaryjnej.

\section{Środowisko pozaseminaryjne}

Powołanie kapłańskie rodzi się w konkretnej wspólnocie rodzinnej i parafialnej, z którą kleryk utrzymuje nadal kontakt, pomimo rozłąki związanej $z$ formacją w seminarium. Najpewniej to rodzice potrafią dość dobrze rozeznać predyspozycje swojego syna do ewentualnej po-

\footnotetext{
${ }^{53}$ PDV 59.

${ }^{54}$ Por. PDV 69.
} 
sługi służebnej w Kościele. Doświadczenie uczy, że rodzina jest wielkim wsparciem dla kiełkującego powołania; zarówno przez pomoc duchową, która może się wyrażać w modlitwie, jak również przez dobry przykład czy słowo umocnienia. Powracający do domu alumn, który czuje akceptację rodziców, może mieć większą wolność w podejmowaniu dalszych kroków formacyjnych. Zdarza się jednak, że rodzice wyraźnie przeciwstawiają się powołaniu syna lub są obojętni wobec jego decyzji. Konfrontacja $\mathrm{z}$ ich poglądami może wpłynąć na szybsze dojrzewanie kandydata do decyzji o kapłaństwie. W każdym razie rodzice, rodzeństwo i inni członkowie rodziny zachęcani są do tego, by nie osądzali wyboru ich krewnego kategoriami ludzkiej (światowej) logiki, ale z szacunkiem towarzyszyli mu i otwierali na „wypełnienie woli Bożej”55.

Niemały wkład w kształtowanie się powołania młodego człowieka ma rodzima wspólnota parafialna. Zdecydowana większość alumnów przed wstąpieniem do seminarium należy do służby ołtarza w swojej parafii, przez co są oni rozpoznawalni przez znaczną część parafian. Wspólnota parafialna, w której kleryk przeżył mocne doświadczenie Kościoła, powinna pamiętać o nim w modlitwie i stwarzać okazje do „sprawdzenia w praktyce jego misyjnego powołania” ${ }^{56}$.

Szczególną rolę w rozeznawaniu powołania młodego człowieka mają kapłani, którzy w jedności z biskupem diecezjalnym mają troszczyć się o formację seminarzystów ${ }^{57}$. Przykład prawdziwej, ofiarnej i życzliwej postawy kapłańskiej proboszcza i jego współpracowników pociąga za sobą tych, którzy chcą naśladować tę formę służby Bogu i ludziom. Benedykt XVI trafnie to scharakteryzował w znanej wypowiedzi, że wierni oczekują od kapłana, by był „ekspertem w dziedzinie życia duchowego. Dlatego, gdy młody kapłan stawia swoje pierwsze kroki, potrzebuje u swego boku poważnego mistrza, który mu pomo-

\footnotetext{
${ }^{55}$ PDV 68.

${ }^{56}$ PDV 68.

${ }^{57}$ Por. RFIS 129.
} 
że, by nie zagubił się pośród propozycji kultury chwili"58. Kapłani lokalnego Kościoła mają więc pełnić rolę mistrza, który współpracując z wychowawcami seminaryjnymi, odpowiedzialnie towarzyszy dojrzewaniu powołania młodego człowieka.

\section{Środowisko seminaryjne}

Dokument Ratio fundamentalis wyraźnie stwierdza, że głównym odpowiedzialnym za przyjęcie do seminarium, jak również za opracowanie zasad seminaryjnej formacji jest biskup diecezjalny. Odpowiedzialność ta wyraża się przez powołanie wspólnoty formatorów na czele $\mathrm{z}$ rektorem i częste $\mathrm{z}$ nimi kontakty, potwierdzające zaufanie i wsparcie $\mathrm{w}$ działaniach wychowawczych. Jednocześnie biskup powinien mieć osobisty kontakt $z$ alumnami, aby czuwać nad ich postępami i decyzjami, zwłaszcza w perspektywie święceń, których ma im udzielić $^{59}$. W tym sensie towarzyszy w procesie rozeznawania, zapoznając się z opiniami wspólnoty formatorów, a także z opiniami środowiska pozaseminaryjnego i ostatecznie dopuszcza alumnów do kolejnych etapów formacji, a w szczególności do posług i święceń.

Ścisłe środowisko seminaryjne tworzą zarówno alumni, jak również wspólnota formatorów. Praktyka pokazuje, że konseminarzyści są najbliższymi i bacznymi obserwatorami każdego rozwijającego się w seminarium powołania. Jak już wcześniej wspomniano, są oni wezwani w duchu odpowiedzialności do braterskiego pouczenia w przypadku wyraźnych nadużyć moralnych, ale również do zgłoszenia formatorom ewentualnych przeszkód do święceń, które zostałyby odkryte. Dynamika grupy ma jednak przede wszystkim w pozytywny sposób wpływać na wzajemne motywowanie się $\mathrm{w}$ drodze do kapłaństwa.

Wspólnotę formatorów tworzy rektor wraz z pomagającymi mu przełożonymi i ojcami duchownymi. „Zachowując rozróżnienie po-

${ }^{58}$ Benedykt XVI, Przemówienie do kapłanów zgromadzonych $w$ archikatedrze warszawskiej, „L'Osservatore Romano”, 6-7(2006), s. 16.

${ }^{59}$ Por. RFIS 128. 
między forum wewnętrznym a zewnętrznym (...), cała wspólnota wychowawców powinna solidarnie dzielić się odpowiedzialnością za wychowanie kandydatów do kapłaństwa" ${ }^{60}$. I tak K. Dyrek wylicza cztery szczegółowe funkcje formatorów w procesie rozeznawania. Najpierw chodzi o „towarzyszenie”, które ma być obecnością bardzo znaczącą i wymagającą, ale $z$ drugiej strony dyskretną. Formator powinien cechować się w tym względzie umiejętnością pełnienia roli pośrednika w zależności od etapu dojrzałości alumna. Druga funkcja to „stymulowanie" do ciągłego rozeznawania tak, aby seminarzysta sam doszedł do przekonania, że rozeznawanie jest normalnym sposobem życia duchowego. Owa ciągłość zakłada też momenty konfrontacji i kryzysu, które zmuszają do refleksji nad swoimi decyzjami. Ma to chronić kleryka przed ewentualnym przekonaniem, że wybór raz podjęty nie musi być ponawiany. Kolejnym instrumentem formacyjnym jest „dialog”, którego formator nie może pomijać. Formowanie całej grupy czy rocznika nie wystarcza bowiem, aby zagwarantować rozwój indywidualny. Rozeznawanie jest przede wszystkim procesem osobistym, który musi się dokonywać w głębi serca w obecności Boga. Potrzeba zatem, aby osoba formująca, wykorzystując zdolności interpersonalne i zachowując dyskrecję, dawała formowanemu poczucie akceptacji jego indywidualności i odmienności. Kolejna funkcja to „weryfikowanie” dokonanego już wyboru, poprzez refleksję nad jego konsekwencjami i rodzącymi się przy tym uczuciami. Idzie o to, aby weryfikacja odbywała się wspólnie $\mathrm{z}$ osobą rozeznającą. Ważne jest, aby prowadzić osobę z cierpliwością, czasami pozwalając na drobne błędy, które pomogą jej osobiście doświadczyć nieprawdziwości niektórych decyzji pośrednich. Weryfikacja w takiej postaci daje możliwość odnalezienia prawdziwych motywacji działania, które mogą być oparte jedynie na swojej własnej woli, zamiast na planie Bożym ${ }^{61}$.

${ }^{60}$ PDV 66.

${ }^{61}$ Por. K. Dyrek, Rozeznawanie powołania; https://czestochowa-jezuici.pl/2015/04/ 24/rozeznawanie-powolania (dostęp: 19.07.2018). 
Do szerszego gremium środowiska seminaryjnego należą również profesorowie odpowiedzialni za formację intelektualną alumnów. Zadaniem profesorów jest nie tylko przekaz wiedzy, ale również współpraca $\mathrm{w}$ wychowawczym zadaniu seminarium. Powinni oni pomagać słuchaczom w czynieniu postępów zarówno na polu zdobywania wiedzy, jak również w życiu duchowym. Zaleca się również, aby korzystając ze swojego osobistego doświadczenia, wprowadzali do wykładanego przedmiotu elementy formacji duszpasterskiej przyszłych kapłanów ${ }^{62}$.

Cennym uzupełnieniem środowiska seminaryjnego są również specjaliści z różnych dziedzin, a szczególnie z zakresu psychologii. Ratio fundamentalis stwierdza, że ,jest pożytecznym, iż rektor i inni formatorzy mogą liczyć na współpracę ekspertów nauk psychologicznych, którzy jednakże nie mogą należeć do grona wychowawczego"63. Ważne jest, aby wybierani eksperci prezentowali w swoim podejściu do człowieka w pełni chrześcijańską antropologię. Mogą pomóc wówczas w ocenie zdatności psychicznej kandydatów do seminarium, a także udzielać konsultacji w ocenie osobowości w późniejszym okresie formacji, gdyby wystąpiła taka konieczność. Zawsze jednak potrzebna jest pełna przejrzystość w badaniach i pełna zgoda kandydata wyrażona na piśmie $^{64}$.

Zespół przełożonych zewnętrznych jest zobowiązany także do formalnej weryfikacji alumnów przy okazji pięciu momentów w ciągu procesu formacji. Czynności rozeznania zdatności kandydata, określane mianem „skrutynia”, powinny odbyć się przy okazji: kandydatury (admissio), posług (lektoratu i akolitatu) oraz święceń diakonatu i prezbiteratu. Celem tej weryfikacji jest rozeznanie rzeczywistego istnienia przymiotów osobistych kandydata, potrzebnych do podjęcia kolejnych etapów formacji. Jeśli chodzi o ostateczną decyzję dopuszczenia do sakramentu święceń, to odpowiedzialność kanoniczną posiada biskup. Powinien on „odpowiednio wcześnie upewnić się poprzez skrutynia,

\footnotetext{
${ }^{62}$ Por. RFIS 140.

${ }^{63}$ RFIS 192.

${ }^{64}$ Por. RFIS 194-195.
} 
czy każdy z kandydatów jest godny przyjęcia sakramentu święceń i w pełni zdecydowany na życie według wymagań kapłaństwa katolickiego" ${ }^{65}$.

\section{Podsumowanie}

Analiza dokumentów kościelnych dotyczących formacji seminaryjnej, uzupełniona szeregiem uwag praktycznych, prowadzi do podsumowania rozważań i wyciągnięcia ogólnych wniosków.

Wydaje się, że najbardziej istotną cechą rozeznawania w seminarium jest ciągłość tego procesu. Problem rozeznawania towarzyszy formacji w sposób permanentny; widać wyraźnie ewolucyjny charakter tego zadania. U samego początku stawiane jest pytanie natury fundamentalnej: „Czy mam być kapłanem?”. Jednak wraz z postępami w formacji seminarzysta zadaje sobie pytania bardziej szczegółowe: „Co jeszcze mogę zrobić, by zostać najpierw dobrym człowiekiem, a potem dobrym kapłanem?”. Przyszły kapłan ma stać się człowiekiem rozeznania, aby umiał już na stałe „rozpoznawać, jaka jest wola Boża: co jest dobre, co Bogu przyjemne i co doskonałe” (Rz 12,2). Rozeznawanie jest wielką sztuką i nie dotyczy tylko samego powołania. By stać się mistrzem w tej dziedzinie, trzeba najpierw stawać się człowiekiem wolnym, dojrzałym duchowo i osobowo. Przede wszystkim trzeba o to zabiegać każdego dnia. Obrazują to znane słowa J. Lieberta: „Uczyniwszy na wieki wybór, w każdej chwili wybierać muszę"66.

Jeśli ktoś stanie się mistrzem w jakiejś dziedzinie, to może podjąć się prowadzenia innych. Doświadczona na sobie metoda rozeznawania staje się narzędziem, które można wykorzystać do formacji i weryfikacji innych. Uczeń coraz bardziej upodabnia się do mistrza, stając się w rzeczywistości duszpasterskiej prawdziwym przewodnikiem. Potrafi on towarzyszyć w rozeznawaniu, umiejętnie pozwalając na samodziel-

${ }^{65}$ RFIS 203.

${ }^{66}$ J. Liebert, Jeździec; https://literatura.wywrota.pl/wiersz-klasyka/20235jerzy-liebert-jezdziec.html (dostęp: 20.07.2018). 
ne kroki, weryfikując je i pomagając podejmować dalsze decyzje. Jest to możliwe właśnie dlatego, że sam tę drogę przeszedł, co więcej, dalej nią idzie. Na tym polega pouczalność (łac. docibilitas) przyszłego kapłana, że prowadząc innych, nie przestaje być uczniem.

$\mathrm{Na}$ koniec mocno trzeba podkreślić udział całego środowiska formacyjnego w procesie rozeznawania. Powołanie zrodzone we wspólnocie rodzinnej i parafialnej powinno być rozeznawane we wspólnocie seminaryjnej i przeznaczone do kierowania konkretną wspólnotą lokalną. Kapłaństwo nie jest wyborem drogi indywidualnej ascezy, ale posługą wykonywaną w określonej wspólnocie ludu Bożego. Dlatego też proces rozeznawania formacyjnego musi odbywać się w głębokim zaufaniu i dialogu między seminarzystą i formatorami. Jak już zauważono we wstępie, ostateczną instancją weryfikującą powołanie jest głos Kościoła. Jego rolą jest również odpowiednio mocny przekaz misyjny, który dzięki łasce Ducha Świętego dotrze do tych, którzy jeszcze nie rozpoznali w sobie znaków powołania.

\section{Summary}

Discernment in the seminary occurs on two levels: the personal level, in which a man can recognize the voice of God inside himself, and the community level, in which the Church verifies and eventually admits to the Holy Orders. A vocation is a gift, as it comes from God's choice: And no man taketh this honour unto himself, but he that is called of God, as was Aaron (Hebrews 5:4).

The main source of light for the thesis presented is the latest document of the Congregation for the Clergy titled: The Gift of the Priestly Vocation. Ratio fundamentalis institutionis sacerdotalis published by the Vatican on 8 December 2016. The first part of the article takes into consideration the general nature of the discernment process in the 
aspect of each if its stages. The cogitation over this issue is developed by an analysis of the areas of vocation discernment. The last part presents a wider perspective on the discernment process from the point of view of the involvement of the formation environment. The analysis of church documents on the topic of seminary formation with practical notes added leads to the summary of the thesis and to drawing the general conclusions.

It appears that the most essential feature of discernment in the seminary is the continuity of the process. The Church's role is to generate a suitably strong missionary message which, owing to the grace of the Holy Spirit, would reach those who haven't yet discovered the signs of vocation in themselves.

Keywords: seminarist, formator, seminary, vocational discernment, seminary formation.

\section{Bibliografia}

Begasse de Dhaem A., Jezus, Formator formatorów. Wspólnota uczniów jako przestrzeń wzrastania $w$ wierze, [w:] W. Wójtowicz (red.), Formacja seminaryjna jako przestrzeń wzrastania $w$ wierze, Niepokalanów 2017, s. 11-36.

Benedykt XVI, Przemówienie do kapłanów zgromadzonych warchikatedrze warszawskiej, „L'Osservatore Romano”, 6-7(2006), s. 15-17.

Franciszek, Przemówienie do Zgromadzenia Plenarnego Kongregacji ds. Duchowieństwa, „L'Osservatore Romano” 226(2014), s. 30-32.

Jan Paweł II, List do kobiet, AAS 87(1995), s. 809-810.

Jan Paweł II, Pastores dabo vobis, AAS 84(1992), s. 657-804.

Dyrek K., Rozeznawanie powołania; https://czestochowa-jezuici.pl/2015/04/ 24/rozeznawanie-powolania (dostęp: 19.07.2018).

Kodeks prawa kanonicznego (25.01.1983). 
Kongregacja ds. Duchowieństwa, Dar powołania do kapłaństwa. Ratio fundamentalis institutionis sacerdotalis, „L'Osservatore Romano”, Supplement, 8 XII 2016.

Kongregacja ds. Wychowania Katolickiego, Instrukcja dotycząca kryteriów rozeznawania powołania $w$ stosunku do osób $z$ tendencjami homoseksualnymi w kontekście przyjmowania ich do seminariów i przyjmowania do święceń, „L'Osservatore Romano” 5(2006), s. 54-56.

Paweł VI, List apostolski Ad pascendum, AAS 64(1972), s. 536-539.

Tomasz z Akwinu, Suma teologiczna. O Bogu, t. 1, tłum. S. Bełch, Londyn 1978.

Cyran W., Powolanie. Pojęcie, rozeznanie i kierownictwo duchowe, Częstochowa 2003.

Rzeszowski W., Formacja ludzka w przygotowaniu do kapłaństwa, „Rocznik Teologii Katolickiej", XV/1(2016), s. 39-47. 